\title{
Plutonium and Uranium in Japanese Human Tissues
}

\author{
Yasuhito IGARASHi*, Atsushi YamakawA and Nagao IKedA \\ Department of Chemistry, University of Tsukuba \\ Sakura-mura, Ibaraki-Pref. 305, Japan \\ Received March 28, 1987
}

\begin{abstract}
Plutonium and uranium in human tissues obtained from residents of the Tokyo area were determined by $\alpha$-spectrometry and the fission track method, respectively. The distribution pattern of each element was estimated on the basis of mean concentration obtained. Plutonium is concentrated in some special organs, while uranium is distributed rather generally throughout the whole body. This difference of distribution tendency is considered to be due to the characteristics of stable chemical states of the elements in body fluid; $\mathrm{Pu}^{4+}$ for plutonium and $\mathrm{UO}_{2}{ }^{2+}$ for uranium.
\end{abstract} Key Words: plutonium, uranium, human tissue, individual
organ burden, total body burden

\section{Introduction}

Several transuranium elements have been released to the environment by nuclear detonations during these four decades. These nuclides have entered the biosphere with the lapse of time and will behave similarly to naturally occurring actinide elements. Since most of these are long-lived $\alpha$-emitters, it seems that these might bring human beings potentially hazardous low level exposure even in the distant future. From this point of view, comparison of the behaviors of natural actinides with those of artificial ones in the environment could give some information to facilitate the prediction of behaviors of these elements in the future. Among the man-made transuranium nuclides in the environment, ${ }^{239} \mathrm{Pu}$ and ${ }^{240} \mathrm{Pu}$ are especially important, considering their high toxicity, relatively large amounts released (about $330 \mathrm{kCi}^{1}$ ) and long half lives of $2.4 \times 10^{4}$ and $6.6 \times 10^{3}$ years, respectively.

The authors reported in the previous papers $^{2)-4)}$ on the determination of fallout plutonium and uranium in several human tissues of the Japanese. In this paper, plutonium and uranium in human tissues are determined in the additional tissue samples and the analytical data

* Present address: Division of Radioecology, National Institute of Radiological Sciences, 3609, Isozaki, Nakaminato, Ibaraki-Pref. 311-12, Japan. are compared and discussed from the abovementioned point of view.

\section{Methods}

Human tissues analyzed were obtained from the autopsy in a medical study of residents of the Tokyo metropolitan area who died during 1980-82. No information concerning the subject except age, sex and cause of death was available. In this work, plutonium and uranium were determined for the same samples. The samples except bone samples were first lyophilized. Each lyophilized sample or bone sample was ashed at $470-500{ }^{\circ} \mathrm{C}$ on a quartz dish using an electric oven. After ashing, the sample was mixed in an agate mortar sufficiently. Then each sample was divided into two parts; a smaller part (about $10 \mathrm{mg}$ ) was for the determination of uranium, and the rest for plutonium.

Plutonium was chemically separated and electrodeposited on a stainless steel disk, and the $\alpha$-activity was measured by an $\alpha$-spectrometer with a $\mathrm{Si}(\mathrm{Au})$ surface barrier type semiconductor detector. Uranium was determined by the fission track method with calibration curves. Details for the analytical procedures are described in the previous papers ${ }^{2)-4}$.

\section{Results and Discussion}

3.1 Concentration distribution of plutonium 
Table 1 Concentrations of plutonium in human

\begin{tabular}{lccr}
\multicolumn{2}{c}{ tissues } & \multicolumn{1}{c}{$(\mu \mathrm{Bq} / \mathrm{g}$ wet $)$} \\
\hline Tissue & $\begin{array}{c}\text { Number } \\
\text { of } \\
\text { samples* }\end{array}$ & $\begin{array}{c}\text { Arith. mean } \\
(\sigma)\end{array}$ & $\begin{array}{c}\text { Geo. mean } \\
(\sigma \mathrm{g})\end{array}$ \\
\hline Lung & 17 & $3(3)$ & $2(2.2)$ \\
Liver & 18 & $22(16)$ & $15(3.0)$ \\
Kidney & $11(10)$ & $2(2)$ & $1(2.5)$ \\
Spleen & $3(2)$ & $2(2)$ & $1(4.7)$ \\
Muscle & 11 & $2(3)$ & $1(2.5)$ \\
Heart & $5(4)$ & $1(4)$ & $1(1.4)$ \\
Bone** & 11 & $9(6)$ & $7(2.2)$ \\
\hline
\end{tabular}

* The number of samples available for calculation of arithmetic and geometric means is shown in parentheses

** Bone samples were taken from rib and femur

Table 2 Concentrations of uranium in human tissues (ppb wet)

\begin{tabular}{lccc}
\multicolumn{3}{c}{ tissues } & $(\mathrm{ppb}$ wet $)$ \\
\hline Tissue & $\begin{array}{c}\text { Number } \\
\text { of } \\
\text { samples }\end{array}$ & $\begin{array}{c}\text { Arith. mean } \\
(\sigma)\end{array}$ & $\begin{array}{c}\text { Geo. mean } \\
(\sigma \mathrm{g})\end{array}$ \\
\hline Lung & 22 & $1.35(1.03)$ & $1.08(1.96)$ \\
Liver & 19 & $0.21(0.10)$ & $0.19(1.59)$ \\
Kidney & 22 & $0.39(0.22)$ & $0.33(1.81)$ \\
Spleen & 15 & $0.20(0.10)$ & $0.18(1.87)$ \\
Muscle & 22 & $0.57(0.45)$ & $0.47(1.89)$ \\
Heart & 5 & $0.44(0.31)$ & $0.29(3.75)$ \\
Cerebrum & 2 & $0.15(0.01)$ & $0.15(1.10)$ \\
Bone* & 20 & $0.69(0.29)$ & $0.62(1.60)$ \\
\hline
\end{tabular}

* Bone samples were taken from skull, rib and femur

and uranium in human tissues

The results obtained for plutonium are summarized in Table 1. In the table geometric mean values with geometric standard deviations are given in addition to arithmetic mean values, because plutonium concentrations in tissues indicate a log-normal distribution as shown in Fig. 1, as other authors have pointed out ${ }^{(5)-8)}$. The results for uranium are given in Table 2. Uranium concentrations in individual tissue also reveal a log-normal distribution as shown in Fig. 2, which is of the same tendency as most of other trace elements in human tissues. It should be noted that plutonium and uranium concentrations in bones, regardless of the kind of bone, may compose a single population (Fig. 3 ). Generally speaking, the concentrations of essen-

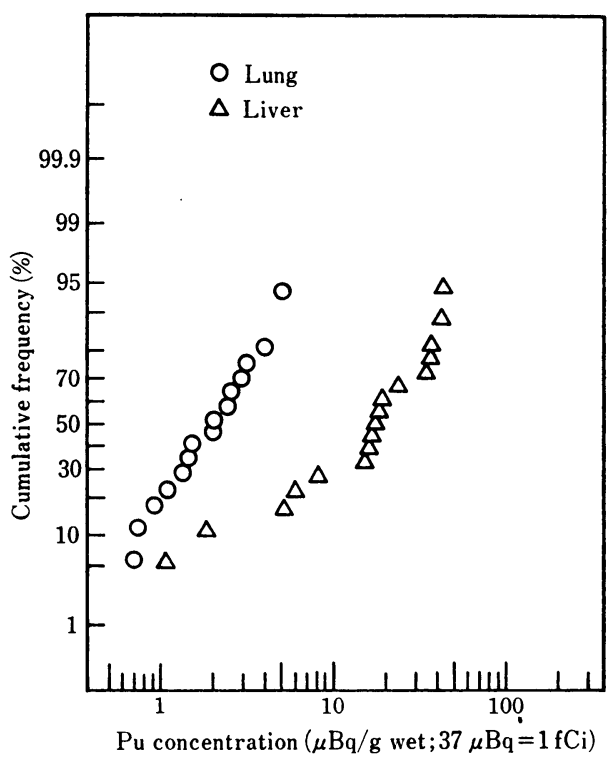

Fig. 1 Cumulative frequency curves of $\mathrm{Pu}$ concentrations in human lung and liver samples.

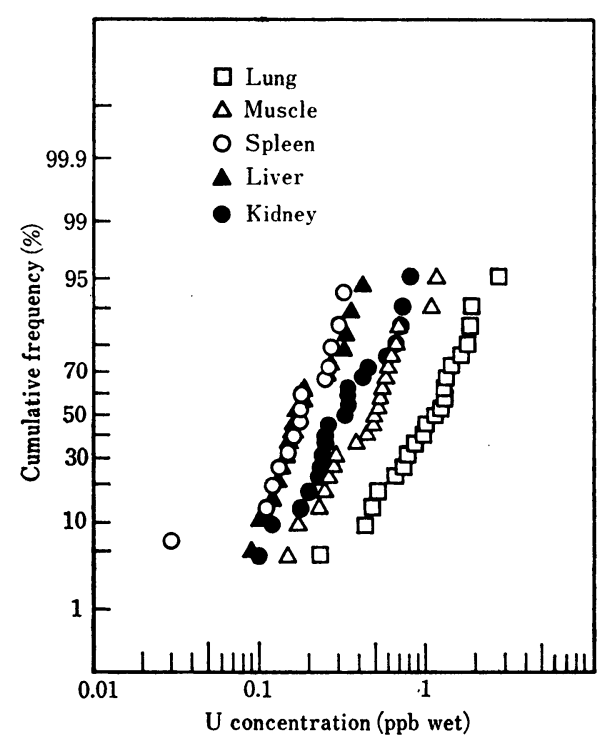

Fig. 2 Cumulative frequency curves of $U$ concentrations in several human soft tissues.

tial elements in the tissues of living beings, even if they are trace elements, tend to maintain nearly constant values by the homeokinesis. Their concentrations, therefore, are not affected by the increase or decrease in intake or excretion amounts, and their concentration distributions in the tissues of living beings are normal 
Table 3 Weights and compositions of the composite samples

\begin{tabular}{|c|c|c|c|c|c|c|}
\hline \multirow{2}{*}{ Age, Sex } & \multicolumn{2}{|c|}{ Kidney } & \multicolumn{2}{|c|}{ Spleen } & \multicolumn{2}{|c|}{ Muscle } \\
\hline & Wt. (g) & Comp. (\%) & Wt. (g) & Comp. (\%) & Wt. (g) & Comp. (\%) \\
\hline $72, \mathrm{M}$ & 254.3 & 17.6 & 20.8 & 5.4 & 218.9 & 20.8 \\
\hline $68, \mathrm{M}$ & 264.0 & 18.3 & 52.7 & 13.7 & 43.6 & 4.1 \\
\hline $62, \mathrm{M}$ & - & & 103.1 & 26.8 & 41.3 & 3.9 \\
\hline $78, \mathrm{M}$ & 218.6 & 15.2 & 42.6 & 11.1 & 523.7 & 49.8 \\
\hline $70, \mathrm{M}$ & 189.0 & 13.1 & 70.7 & 18.4 & 47.2 & 4.5 \\
\hline $73, \mathrm{M}$ & 285.1 & 19.8 & & & 86.5 & 8.2 \\
\hline $53, \mathrm{~F}$ & 231.4 & 16.0 & 95.0 & 24.7 & 90.5 & 8.6 \\
\hline Total & 1442.4 & 100 & 384.9 & 100 & 1051.7 & 100 \\
\hline
\end{tabular}

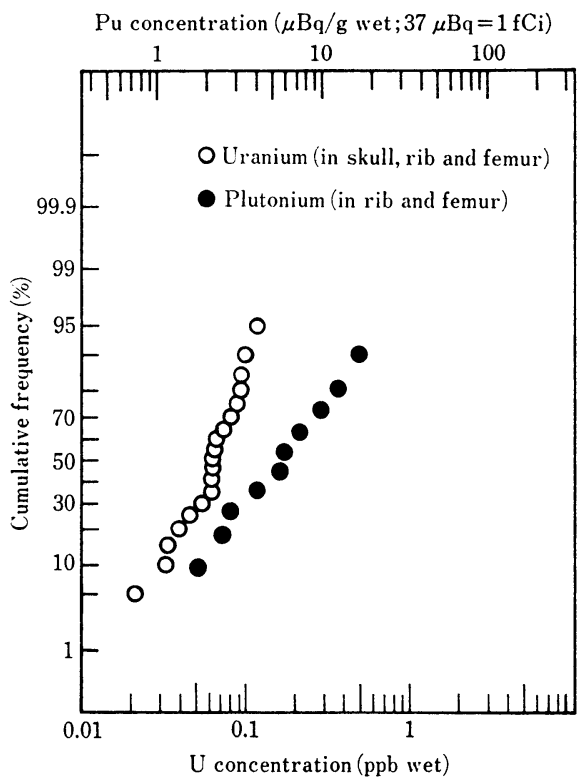

Fig. 3 Cumulative frequency curve of $\mathrm{Pu}$ and $\mathrm{U}$ concentrations in human bones.

distributions. On the other hand, the concentration of non-essential elements are affected by their increase or decrease in the environment, thus their concentration distributions are log-normal distributions ${ }^{9}$. Considering these facts, uranium, as well as plutonium, is a nonessential element for man.

3.2 Distribution patterns of plutonium and uranium among human tissues

The individual organ burden (IOB) and the total body burden (TBB) of the elements for the ICRP Reference $\mathrm{Man}^{10)}$, which were estimated in the previous papers ${ }^{2), 8}$, were re-estimated by
Table 4 Concentrations of plutonium in the composite samples

\begin{tabular}{lcc}
\hline Tissue & $\mathrm{Pu}(\mu \mathrm{Bq} / \mathrm{g}$ wet $)$ & Yield $(\%)$ \\
\hline Kidney & $0.44 \pm 0.07$ & $90.7 \pm 3.5$ \\
Spleen & $1.3 \pm 0.3$ & $87.9 \pm 3.4$ \\
Muscle & $0.07 \pm 0.04$ & $77.5 \pm 3.2$ \\
\hline
\end{tabular}

Errors represent counting statistics of $1 \sigma$

adding new data. As plutonium activities in muscle, kidney and spleen are rather low and the corresponding counting statistics are not so good, the analytical values previously obtained for these tissues were not sufficiently accurate. Therefore, in order to obtain more reliable data for the plutonium levels in the tissues, a composite sample for each tissue was analyzed. Each composite sample was prepared by mixing each corresponding tissue from six or seven subjects, the weights and compositions of which are shown with age and sex in Table 3.

Table 4 shows plutonium concentrations found in these composite samples. Plutonium contents were rather significant in spleen and kidney, while unexpectedly low in muscle. Okabayashi $^{11)}$ pointed out that plutonium is concentrated in spleen. In our result obtained with about $0.4 \mathrm{~kg}$ of spleen, however, not so high concentration as in liver nor in lung was observed.

Based on the results, a new TBB value of plutonium was estimated as shown in Table 5 . The TBB value is smaller than the previously reported one $\mathrm{e}^{3)}$ by about $40 \mathrm{mBq}(1 \mathrm{pCi})$. It. should be noted that this estimation was made on the basis of mean concentration. The IOB. 
Table 5 Estimated organs and total body burdens of ${ }^{239,240} \mathrm{Pu}$ for the ICRP Reference Man

\begin{tabular}{lcccc}
\hline Tissues & $\begin{array}{c}\text { ICRP Ref. Man } \\
\text { Weight }(\mathrm{g})\end{array}$ & $\begin{array}{c}\text { Pu concn. } \\
(\mu \mathrm{Bq} / \mathbf{g} \text { wet })\end{array}$ & $\begin{array}{c}\text { Organ } \\
\text { burden }(\mathrm{mBq})\end{array}$ & $\begin{array}{c}\text { Organ/Total } \\
(\%)\end{array}$ \\
\hline Lungs & 1000 & 3 & 3 & 2 \\
Liver & 1800 & 22 & 40 & 30 \\
Kidneys & 310 & 0.44 & 0.1 & 0.1 \\
Spleen & 180 & 1.3 & 0.2 & 0.2 \\
Muscle & 28000 & 0.07 & 2 & 2 \\
Skeleton & 10000 & 9 & 90 & 60 \\
Others & 28710 & $0.04^{*}$ & 10 & 100 \\
\hline Total & 70000 & & 150 & \\
\hline
\end{tabular}

* An assumed value

Table 6 Estimated uranium organs and total body burdens for the ICRP Reference Man

\begin{tabular}{lcccc}
\hline Tissue & $\begin{array}{c}\text { ICRP Ref. Man } \\
\text { Weight }(\mathrm{g})\end{array}$ & $\begin{array}{c}\text { U concn. } \\
(\mathrm{ppb} \text { wet })\end{array}$ & $\begin{array}{c}\text { Organ } \\
\text { burden }(\mu \mathrm{g})\end{array}$ & $\begin{array}{c}\text { Organ/Total } \\
(\%)\end{array}$ \\
\hline Lungs & 1000 & 1.4 & 1.4 & 4 \\
Liver & 1800 & 0.21 & 0.38 & 1 \\
Kidneys & 310 & 0.39 & 0.12 & 0.3 \\
Spleen & 180 & 0.20 & 0.04 & 0.1 \\
Muscle & 28000 & 0.57 & 16 & 40 \\
Heart & 330 & 0.44 & 0.15 & 0.4 \\
Brain & 1400 & 0.15 & 0.21 & 0.5 \\
Skeleton & 10000 & 0.69 & 6.9 & 20 \\
Blood & 5500 & $0.84^{*}$ & 4.6 & 10 \\
Others & 21480 & $0.3^{* *}$ & 6 & 10 \\
\hline Total & 70000 & & 40 & 100 \\
\hline
\end{tabular}

* See Ref. 2

** A value estimated from the average of liver, kidney, spleen, muscle, heart and brain

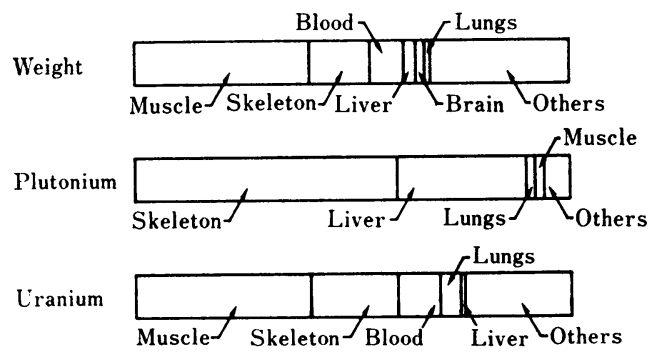

Fig. 4 Distribution patterns of $\mathrm{Pu}$ and $\mathrm{U}$ among human tissues with weight distribution for the ICRP Reference Man.

and TBB values of uranium also obtained by using the mean concentrations are shown in Table 6.
Using the data, the distribuiton patterns of these elements among human tissues and organs were illustrated as shown in Fig. 4, comparing with the weight distribution of tissues for the ICRP Reference $\mathrm{Man}^{10}$. It is evident that uranium is distributed rather uniformly all over the body, while plutonium is concentrated in skeleton $(60 \%)$ and liver $(30 \%)$, reconfirming that these two organs are important for systemic distribution of plutonium. ICRP Publication 48 reviewed and summarized the distribution of fallout plutonium in members of the general population from various geographical regions, suggesting the deposition percentage of $45 \%$ for liver and $35 \%$ for skeleton as weighted mean of the data ${ }^{12)}$. It also shows, however, the 
variations in relative partition of plutonium in these organs, which ranged between 23 and $55 \%$ for liver and 25 and $56 \%$ for skeleton. Major uncertainty may be due to the difficulty how the total skeletal content should be estimated from fragmentary data, which is beyond the scope of the present work. In Tables 5 and 6 , the skeletal contents of plutonium and uranium calculated from small number of different bone samples are shown. The present work, therefore, provides preliminary estimates of skeletal burdens of both plutonium and uranium.

Behaviors of these elements in human body should be associated with hydrolysis and the complex formation of the ions in body fluid. Generally speaking, the activity of an ion species in a solution is affected by its ionic radius and electric charge (the so-called charge density of the ion). The different trend of distribution of the two elements in human body can be interpreted by the difference of stable species present in body fluid. Both plutonium and uranium similarly have four oxidation states from III to VI and they take normally either IV or VI $\mathrm{Pu}^{4+}, \mathrm{U}^{4+}$ or $\mathrm{PuO}_{2}{ }^{2+}$, $\left.\mathrm{UO}_{2}{ }^{2+}\right)^{13)}$. It seems, however, that plutonium is most stable in the tetravalent state in body fluid, while uranium is most stable in the hexavalent state.

It is naturally supposed that the plutonium ion of higher charge and smaller radius does not exist by itself in human body fluid. In body fluid, there are many organic matters such as proteins, amino acids and other organic acids, etc. that act as complex ligands for metal ions. The complex formation ability of plutonium ions decreases in the order of $\mathrm{Pu}$ (IV) $>\mathrm{Pu}$ (III) $>\mathrm{Pu}(\mathrm{VI})>\mathrm{Pu}(\mathrm{V})^{\left.13),{ }^{14}\right)}$. According to the review by Taylor $^{14)}$, a major part of plutonium exists as rather stable complexes of $\mathrm{Pu}(\mathrm{IV})$ with plasma proteins, $\beta_{1}$-globulin such as transferrin, etc. in human beings and several mammals.

On the other hand, hydrolysis is closely related to the complex formation of an ion. It is said that the $\mathrm{Pu}(\mathrm{IV})$ ion undergoes the most extensive hydrolysis of all the plutonium ions, and the tendency towards hydrolysis decreases in the order of $\mathrm{Pu}(\mathrm{IV})>\mathrm{Pu}(\mathrm{VI})>\mathrm{Pu}$ (III) $>$ $\mathrm{Pu}(\mathrm{V})^{13), 14}$. The equilibrium constant for the first step of $\mathrm{Pu}(\mathrm{IV})$ hydrolysis with proton eliminaiton, ${ }^{*} K_{1}$, according to the nomenclature defined by Sillen and Martell $^{15)}$, was reported to be $-1.94--1.26$ at $25^{\circ} \mathrm{C}$ and -1.06 at $34^{\circ} \mathrm{C}$, close to body temperature ${ }^{14)}$. Therefore, at physiological pH, Pu(IV) ions mostly hydrolyse, and through successive hydrolysis, proceed to form highly insoluble polymers of $\mathrm{Pu}(\mathrm{OH})_{4}$, solubility product of which was calculated to be $7 \times 10^{-5013}$. In addition, the second step of hydrolysis is said to be irreversible ${ }^{13)}$. In the review, it is described that $\mathrm{Pu}(\mathrm{IV})$ was found to be present as "pseudocolloid" between $\mathrm{pH}$ $2.8-7.5$ at $6.8 \times 10^{-8} \mathrm{M}^{14)}$. Provided that all of plutonium present in the human body, 150 $\mathrm{mBq}$ (4 pCi), were ${ }^{230} \mathrm{Pu}$ and that it were dissolved in $5200 \mathrm{ml}$ of blood ${ }^{10)}$, its concentration would be $5 \times 10^{-14} \mathrm{M}$.

Plutonium deposition in the liver is attributed to the hydrolysis of the ion and the polymer formation of hydroxide, followed by the deposition of the polymer on reticuloendothelial system $^{16)}$. Spleen also contains reticuloendothelial system in its tissue ${ }^{17)}$, relatively high plutonium concentration in spleen might be due to the deposition of plutonium polymer on this cell system.

As for uranium, it seems that uranyl ions form stable soluble complex ions with carbonate ions, such as $\left[\mathrm{UO}_{2}\left(\mathrm{CO}_{3}\right)_{2}\right]^{2-}$ or $\left[\mathrm{UO}_{2}\left(\mathrm{CO}_{3}\right)_{3}\right]^{4-}$. The stability constants of uranyl carbonate in the literature are high, 14.6-15.6 for $\beta_{2}$ and 18.3-23 for $\beta_{3}$ around at $25^{\circ} \mathrm{C}^{14)}$. In the review by Gindler ${ }^{18}$, it is described that $60 \%$ of $U(V I)$ in the blood is bound with bicarbonate and that $47 \%$ of $\mathrm{U}(\mathrm{VI})$ in the blood is associated with the inorganic part of plasma, $32 \%$ with protein and $20 \%$ with erythrocytes. In the review, stability constants $(\beta)$ and the number of ligand bound $(n)$ were also given for $U(V I)$ and bicarbonate, plasma albumin and lipoprotein of erythrocyte; $\beta=18.04, n=1.7$ for bicarbonate complex; $\beta=10.48, \quad n=0.6$ for plasma albumin; $\beta=8.90, n=0.46$ for erythrocytic lipoprotein. Thus, uranyl carbonate complex ions are the most important, considering physiological behaviors of uranium in the human body. 
On the hydrolysis of uranium ions, the same observation can be made as for plutonium ions. The tendency of hydrolysis decreases in the order of $\mathrm{U}(\mathrm{IV})>\mathrm{U}(\mathrm{VI})>\mathrm{U}(\mathrm{III})^{13), 18)}$. Stability constant ${ }^{*} K_{1}$ was reported to be almost in the range of $-1--2$ for U(IV) and $-4--6$ for $U(V I)$ around at $25^{\circ} \mathrm{C}^{15), 18}$. Both U(IV) and U(VI) form hydroxide polymers in the hydrolysis process. It is said that $\mathrm{U}(\mathrm{VI})$ hydroxide is dissolved by the addition of strongly complexing agents such as citrate or bicarbonate, while U(IV) hydroxide is not ${ }^{18)}$. There seems to be a similar phenomenon occurring in $\mathrm{Pu}(\mathrm{IV})$ ions in the hydrolysis. If uranium taken into man were in tetravalent state, a distribution pattern among the tissues similar to that of plutonium would be expected.

In conclusion, plutonium and uranium taken into man exist in body fluid mainly as complexes of $\mathrm{Pu}(\mathrm{IV})$ and $\mathrm{U}(\mathrm{VI})$, respectively. Consequently, a part of plutonium in the tetravalent state is readily hydrolysed, resulting in insoluble polymers that finally deposits in the liver, while uranium, forming stable soluble complexes with carbonate, is distributed and deposited in every part of human body. The above-mentioned discussion is reasonable at higher concentration levels. From the results obtained in the present work, it seems possible to conclude that this fact holds even at extremely low level of plutonium and the naturally occurring level of uranium.

\section{Acknowledgement}

The authors greatly appreciate to Professor Tokuzo Kojima, School of Medicine, Nihon University, Professors Tadashi Kitagawa, Eiko Sairenji and Kazunari Moriwaki, School of Dentistry, Nihon University for their kind discussion.

This work was supported in part by the Inter-University Program for the Common Use of the Reactors at Rikkyo University and at Japan Atomic Energy Research Institute. A part of the expenses was covered by a grant from the Ministry of Education, Science and Culture of Japan, to which the authors' thanks are due.

\section{References}

1) Hardy, E.P., Krey, P.W. and Volchok, H.L.: Nature, 241, 444-445 (1973)

2) Igarashi, Y., Seki, R. and Ikeda, N.: Radioisotopes, 33, 55-59 (1984) (in Japanese)

3) Igarashi, Y., Yamakawa, A., Seki, R. and Ikeda, N.: Health Phys., 49, 707-712 (1985)

4) Igarashi, Y., Seki, R. and Ikeda, N.: J. Radiat. Res., 27, 213-218 (1986)

5) Campbell, E.E., Milligan, M.F. and Moss, W.D. et al.: LA-4875, Los Alamos Scientific Laboratory of the University of California, New Mexico (1973)

6) Fisenne, I.M., Cohen, N., Neton, J.W. and Perry, P.: Radiat. Res., 83, 162-168 (1980)

7) Popplewell, D.S., Ham, G.J., Johnson, T.E. and Barry, S.F.: Health Phys., 49, 304-309 (1985)

8) Takizawa, Y., Hisamatsu, S. and Abe, T.: Radiat. Res., 109, 245-255 (1987)

9) Underwood, E.J.: "Trace Elements in Human and Animal Nutrition (3rd Ed.)", translated by Japan Chemical Society, Maruzen, Tokyo (1975) (in Japanese)

10) International Commission on Radiological Protection, "Report of the Task Group on Reference Man", ICRP Publication 23, Pergamon Press, Oxford (1974)

11) Okabayashi, H.: Project Report for a Grant-in-Aid for Scientific Research from the Ministry of Education, Science and Culture of Japan, (A) 57380017, 15-19 (1984) (in Japanese)

12) International Commission on Radiological Protection, "The Metabolism of Plutonium and Related Elements", ICRP Publicaiton 48, Pergamon Press, Oxford (1986)

13) Katz, J.J. and Seaborg, G.T.: "The Chemistry of the Actinide Elements", translated by Miyake, Y., Tominaga, H. and Sugimura, Y. et al., Asakurashoten, Tokyo (1962) (in Japanese)

14) Taylor, D.M.: "Chemical and Physical Properties of Plutonium" in "Uranium, 
Plutonium, Transplutonium Elements", (Ed. by Hodge, H.C., Stannard, J.N. and Hursh, J.B.), pp. 323-347, Springer Verlag, Berlin (1973)

15) Sillen, L.G. and Martell, A.E.: "Stability Constants of Metal-Ion Complexes", The Chemical Society, London (1964)

16) Suzuki, M.: "Harm and Precautionary Measures (Shougai to yoboutaisaku)" in "Plutonium" (Ed. by Nakai, T., Saito, N. and Ishimori, T.), Mukikagaku-zensho XVII-2, Maruzen, Tokyo (1967) (in Japa- nese)

17) Ed. by Yamada, T., Maekawa, F. and Egami, F. et al.: "Dictionary in Biology (Seibutsugaku-jiten)", Iwanamishoten, Tokyo (1983) (in Japanese)

18) Gindler, J.E.: "Physical and Chemical Properties of Uranium" in "Uranium, Plutonium, Transplutonium Elements" (Ed. by Hodge, H.C., Stannard, J.N. and Hursh, J.B.), pp. 69-164, Springer Verlag, Berlin (1973)

要旨

\section{日本人臓器中のプルトニウムとウラン}

五十嵐康人, 山川敦志, 池田長生

筑波大学化学系, 305 茨城県新治郡桜村天王台1-1-1

\footnotetext{
東京近郊居住者の臓器中のプルトニウムとウランを定量し, それらの分布を比較した。プルトニ ウムは $\alpha$ 線スペクトロメトリで, ウランはフィッショントラック法で定量した。プルトニウムとウ ランの体内分布のパターンを平均濃度値をもとに見積った。プルトニウムは特定の臓器に集積する のに対し, ウランは比軦的体全体に分布する傾向が認められる。両元素の分布の達いは, 体液中で 安定に存在する両元素の化学状態 (プルトニウム $\mathrm{Pu}^{4+}$, ウラン $\mathrm{UO}_{2}{ }^{2+}$ ) や化学的性質の差による ところが大きいと考えられる。
} 